\title{
BREXIT, EEA AND THE FREE MOVEMENT OF WORKERS: STRUCTURAL CONSIDERATIONS ON FLEXIBILITY ${ }^{1}$
}

\author{
Václav Stehlík \\ Faculty of Law, Palacky University Olomouc, Czech Republic \\ vaclav.stehlik@upol.cz
}

STEHLÍK, Václav. Brexit, EEA and the free movement of workers: structural considerations on flexibility. International and Comparative Law Review, 2016, vol. 16, no. 2, pp. 145-156. DOI: 10.1515/iclr-2016-0020.

\begin{abstract}
Summary: The article focuses on the regulation of the free movement of workers under Agreement on the European Economic Area in the light of the considered accession of the United Kingdom to this agreement after the Brexit takes place. The participation in the European Economic Area would keep the United Kingdom part of the EU internal market including the free movement of workers. The article tries to answer the question on the degree of flexibility in the EEA Agreement which would give space for the UK to pursue its own policies on the movement of workers. The article argues that structurally the EEA Agreement gives a space for some flexibility, however, only in case of very specific circumstances.
\end{abstract}

Keywords: free movement of persons, Brexit, Agreement on the European Economic Area, EFTA.

\section{Introductory remarks}

In June 2016 the British voters decided that the United Kingdom should leave the European Union. One of the main topics in the pre-referendum campaign was the status of migrant workers coming from other EU countries, especially from Eastern Europe. The British pro-exit politicians called strongly for restrictions of the free movement of workers and their access to social benefits in the host Member State. One of the main concerns was that migrant workers reduce the offer of jobs available to the British citizens and overburden national social security system. ${ }^{2}$ The benefits or losses derived from the free movement of workers have been discussed elsewhere and will not be a main concern of this article. ${ }^{3}$ An assumption that in some sectors the effects of inflow of cheap labour force

1 The article was prepared with the support of Jean Monnet Chair, „EU Law in Global Perspective“.

2 For these arguments, see f.e. http://campaignforanindependentbritain.org.uk/border-control/.

3 For analysis of Brexit impact on EU industries see f.e.:

http://www.migrationobservatory.ox.ac.uk/resources/reports/potential-implications-ofadmission-criteria-for-eu-nationals-coming-to-the-uk/. 
has significantly changed employment patterns may be true and may cause justified worries for the British citizens. At the same time, effects of immigration from the overall economic perspective seem to be evaluated positively. ${ }^{4}$

Anyway, it is most certain that the movement of workers will play a key role in the process of shaping post-Brexit relations to the EU. The solution will depend on the legal outcomes of the exit negotiations. Pro-exit campaigners often suggested that the UK should follow the Norwegian model based on the Agreement on the European Economic Area ${ }^{5}$ concluded between countries grouped in European Free Trade Association ${ }^{6}$ and the EU. The UK accession to the EFTA and, then, as an EFTA Member State, to EEA Agreement might seem one of the first-sight options for the UK. Still, the sense of romance of the homecoming of the former EFTA Member State may not be a reliable guide as the ex-partners from EFTA have moved a long way forward since then, and their relations to the EU became much more complex ${ }^{8}$ and closer than any time before.

Definitely, any prospect relationship, including EEA Agreement, requires a common accord of both the UK and the EU and will not be a one-sided choice. Interestingly some scholars ${ }^{9}$ refused this consensus requirement. They deduced from the wording of EEA Agreement that the UK could automatically continue in its membership based on the succession of its present status even without an EFTA membership and a new ratification process on its accession to EEA. ${ }^{10}$ The arguments put forward in this regard are interesting but, in our opinion, too much purpose-oriented. The interpretation of EEA Agreement in favour of this solution is rather clumsy from both the legal ${ }^{11}$ and political point of view. Even if disregarding the strict legal assessment, this reading of the EEA Agreement would have to be persuasive and acceptable also for the UK's partners, namely the EU and the EFTA states. It would actually have to be acceptable even for the UK as the liberalisation of free movement of workers in the EEA Agreement is

4 For a commentary on the effects of immigration on British employment sector see f.e.: https://www.theguardian.com/politics/2016/may/20/reality-check-are-eu-migrants-really-taking-british-jobs; https://www.theguardian.com/uk-news/2014/nov/05/uk-magnethighly-educated-migrants-research.

5 Further referred as "EEA Agreement".

6 Further referred as "EFTA" and "EEA EFTA states".

7 The UK being a founding member of EFTA in 1960.

8 Most evidently in Switzerland that refused EEA Agreement in referendum. Afterwards it concluded a number of agreements taking over EU internal market rules including free movement of persons. Most recently, the Swiss people refused the EU-Swiss agreement on movement of person in 2014 and Swiss government is obligated to renegotiate it with the EU until February 2017.

9 Yarrow, George. Brexit and the Single Market. Essays in Regulation. Oxford: Regulatory Policy Institute, 2016, No 6.1.

10 Including also ratification in all EU Member States.

11 See f.e. a reaction to Yarrow's analysis in Richard North's paper published here: http:// eureferendum.com/blogview.aspx?blogno $=86236$. 
very advanced (as will be shown below) and it might be reasonably expected that the UK would desire to alter at least some features in that regard during the accession negotiations. ${ }^{12}$

Therefore, the decision on the part of UK to participate on EEA Agreement must go hand in hand with a consent of the EU as well as the EEA EFTA states. ${ }^{13}$ This does not automatically mean that both the EU and the UK will not have its own vision of mutual liaisons and own priorities to be reflected in the postBrexit relations. Negotiations should not be based strictly on a "take or leave" attitude; the final agreement needs to be properly weighed-out and acceptable for both sides; expectedly, this will be very difficult especially in the area of free movement of persons.

In the following, we will examine the EEA-Agreement option for the UK; especially the question how the status of workers is legally constructed compared to the EU regulation and whether it might be flexible enough to meet the UK expectations.

\section{EEA and EU: varying perspectives, aims, objectives}

Before going into details on the movement of workers it will be useful to shortly pause on the underlying objectives on which both forms of economic integration are founded.

It is well known that the EU integration is not based on purely economic ${ }^{14}$ but also on non-economic principles and objectives. ${ }^{15}$ Among these especially the aim to set up common citizenship and ever closer union ${ }^{16}$ are relevant for the shaping of the free movement of persons which, consequently, goes beyond the pure movement of an economic factor. The underlining principle further reflected in the $\mathrm{EU}$ founding treaties is the prohibition of discrimination not only as far as work conditions are concerned but also in relation to other circumstances in which the free moving person (not only worker) can get in a host

12 Perhaps similarly as was agreed in relation to Lichtenstein, the Protocol VIII and correspondingly Protocol V to the EEA Agreement introduced percentage limits for workers outside Lichtenstein. According to this protocol, sectoral adaptations for Lichtenstein reflected its special geographical situation; thus, we do not think that it is possible to expect the same political and legal solution in relation to the UK.

13 Namely, Norway, Island and Lichtenstein.

14 The Preamble to Treaty on the European Union (TEU) talks among others about strengthening and convergence of Member States' economies, establishment of economic and monetary union including a single and stable currency, promotion of economic and social progress.

15 Such as liberty, democracy and respect for human rights, solidarity between EU nations, democratic and efficient functioning of the institutions, comp. Preamble to the TEU. The economic principles are further worked out in the preamble of Treaty on the Functioning of the EU (TFEU).

16 Comp. Preamble to the TEU. 
Member State. Yet, the approximation between the status of own citizens with those of other Member States does not equal to assimilation. The EU law enables to set up limits based particularly on the respect for national social and health insurance systems ${ }^{17}$ and other fundamental interest of Member States. ${ }^{18}$

Similarly, the Preamble to the EEA Agreement refers to non-economic objectives. ${ }^{19}$ Even though the EEA Agreement shares some objectives of noneconomic character, they are much narrower than those formulated in the EU founding treaties. ${ }^{20}$ Comparatively more emphasis is put on economic issues ${ }^{21}$ and the EEA Agreement principally expanded the EU internal market freedoms and other selected EU policies to the EEA EFTA states. The overarching idea is that the legal environment in all EU and EEA EFTA states should be homogenous so that the movement of economic factors can be smooth and free of any unjustified restrictions. ${ }^{22}$

Whereas in relation to the free movement of persons the EU is based on common citizenship and ever closer union, an objective of the EEA Agreement is the fullest possible realisation of the free movement of four freedoms including persons. This might indicate availability of more divergences in the interpretation of the free movement provisions and, in practice, extent of rights attributed to migrant workers. The objective of "fullest possible free movement" might even resemble "program" or aim" oriented provisions. However, this must be read in line with individual provisions of the Agreement on the free movement, possible exceptions and their enforcement.

From the UK's perspective the crucial issues will be the extent of obligations in relation to workers and availability of exceptions, in other words, flexibility of the obligations of contracting parties.

\section{A brief comparison of free movement rules in EEA and EU law}

The first issue concerns the extent to which EU-origin rules must be incorporated in legal orders of EEA EFTA states. In this regard, it is important to focus particularly on the obligation of EEA EFTA states to comply with the EU primary and secondary law.

17 See Directive 2004/38/EC Directive 2004/38/EC of the European Parliament and of the Council of 29 April 2004 on the right of citizens of the Union and their family members to move and reside freely within the territory of the Member States, OJ L 158, 30.4.2004, p. $77-123$.

18 Namely public policy, public security, protection of health and employment in public service, comp. art. 45 TFEU.

19 Such as contribution to the Europe based on peace, democracy and human rights.

20 The partnership between EU and EFTA states is considered a privileged one based on proximity, common values and European identity.

21 Such as trade liberalisation and cooperation, equal conditions of competition and their enforcement.

22 Comp. indent 4 and 5 of the preamble of the EEA Agreement. 


\subsection{The EEA Agreement and EU primary law}

The free movement of persons is set up in Part III of EEA Agreement; specifically, in art. 28 which regulates status of workers and self-employed persons. This article introduces:

- $\quad$ freedom of movement for workers (art. 1)

- abolition of discrimination based on nationality between workers coming from EU Member States and EEA EFTA States as regards employment, remuneration and other conditions of work and employment (art. 2)

- $\quad$ right to accept offers of employment, move freely within the territory of EU Member States and EEA EFTA states for this purpose, to stay in their territory and remain there after having been employed there (art. 3)

- exceptions based on limitations justified on grounds of public policy, public security, public health and employment in the public service (art. 3 and 4$)$.

As concerns EU primary law, while TEU does not contain any specific regulation of free movement of workers, ${ }^{23}$ all regulation is concentrated in TFEU, namely in its art. 45 . The article 28 of EEA Agreement is a mirror provision as it fully copies article 45 TFEU. Thus, the regulation in EU primary law and EEA Agreement seems to be identical.

\subsection{The EEA Agreement and implementation of EU secondary law}

The extent of individual rights is regulated in EU secondary law setting up details on the rights guaranteed in the primary law and in some respects also consolidating case law of the European Court of Justice (CJEU.) ${ }^{24}$ In practice EU secondary law concerns especially the entry of workers, their right of residence, rights connected to employment, including social security, and justifiable restrictions/exceptions. The obligation to incorporate EU secondary legislation in relation to EEA EFTA states is set up in art. 7 of the EEA Agreement which distinguishes between EU regulations and directives. According to this article:

- an act corresponding to an EU regulation must be made part of the internal legal order of the Contracting Parties (EEA EFTA states) and

- an act corresponding to an EU directive leaves to the authorities of the Contracting Parties (EEA EFTA states) the choice of form and method of implementation.

23 TEU in general speaks about the free movement of persons and the area of freedom, security and justice (art. 3 para 2) and establishment of the internal market (art. 3 para 3).

24 This is clearly visible f.e. in relation to the Directive 2004/38 in relation to the applicability of exceptions from the principle of free movement. 
Evidently article 7 of the EEA Agreement keeps the distinctions between regulations and directives similarly as they are known in EU law. ${ }^{25}$ It does not expressly refer to other acts of the EU law, especially decisions; nevertheless, this does not exclude them from the incorporation in EEA rules. ${ }^{26}$ The acts that must be taken over by EEA countries are enumerated in the annexes to the EEA Agreement and in the decisions of the EEA Joint Committee. Acts referred to or contained both in annexes and the decisions of the Joint Committee are binding upon the contracting parties. ${ }^{27}$

In practice, the implementation of EU secondary legislation in relation to workers is carried out mainly through Annex V of the EEA Agreement. This annex lists the EU legislation, which the EEA EFTA states have to take over. Flexible adaptation to changes of EU legislation is secured through the decisions of the EEA Joint Committee with the competence to insert new EU legislation into the annexes. At present this annex requires the implementation of the fundamental EU law on the free movement of persons, including the Directive 2004/38/EC, ${ }^{28}$ Regulation (EU) No 492/2011, ${ }^{29}$ Commission Implementing Decision 2012/733/EU, ${ }^{30}$ Commission Regulation (EC) No 635/2006, ${ }^{31}$ Council Directive 77/486/EEC ${ }^{32}$ or Directive 2014/54/EU. ${ }^{33}$

Except for Annex V, also Annex VII plays a key role for the free movement of workers as it concerns recognition of qualifications. The EEA EFTA states are

25 Comp. Art. 288 TFEU.

26 Decisions can be made binding by decisions of the EEA Joint Committee, see f.e. Commission Implementing Decision 2012/733/EU of 26 November 2012 implementing Regulation (EU) No 492/2011 of the European Parliament and of the Council as regards the clearance of vacancies and applications for employment and the re-establishment of EURES, OJ L 328, 28.11.2012, p. 21, in Annex V of the EEA Agreement or Commission Decision 2009/17/EC of 19 December 2008 setting up the Committee of Experts on Posting of Workers, OJ L 8, 13.1.2009, p. 26, in Annex XVIII.

27 See in that regard art. 7 EEA Agreement.

28 Directive 2004/38/EC Directive 2004/38/EC of the European Parliament and of the Council of 29 April 2004 on the right of citizens of the Union and their family members to move and reside freely within the territory of the Member States, OJ L 158, 30.4.2004, p. 77-123.

29 Regulation (EU) No 492/2011 of the European Parliament and of the Council of 5 April 2011 on freedom of movement for workers within the Union, OJ L 141, 27.5.2011, p. 1.

30 Commission Regulation (EC) No 635/2006 of 25 April 2006 repealing Regulation (EEC) No $1251 / 70$ on the right of workers to remain in the territory of a Member State after having been employed in that State, OJ L 112, 26.4.2006, p. 9

31 Commission Regulation (EC) No 635/2006 of 25 April 2006 repealing Regulation (EEC) No 1251/70 on the right of workers to remain in the territory of a Member State after having been employed in that State, OJ L 112, 26.4.2006, p. 9.

32 Council Directive 77/486/EEC of 25 July 1977 on the education of the children of migrant workers, OJ No L 199, 6.8.1977, p. 32,

33 Directive 2014/54/EU of the European Parliament and of the Council of 16 April 2014 on measures facilitating the exercise of rights conferred on workers in the context of freedom of movement for workers, OJ L 128, 30.4.2014, p. 8. 
obliged to take over particularly Directive 2005/36/EC. ${ }^{34}$ Annex VII introduced minor adaptations in relation to EEA EFTA states concerning some professions specific to these countries. Further, it took over EU coordinating legislation in this area ${ }^{35}$ and EU rules in relation to legal professions. ${ }^{36}$ The Annex sets up also a soft obligation in relation to non-binding legal acts as the EEA EFTA states do not have to implement these acts but should take notice of them. ${ }^{37}$

Finally, Annex XVIII requires implementation of a number of EU rules on health and safety at work, ${ }^{38}$ equal treatment for men and women ${ }^{39}$ or labour law. ${ }^{40}$

In short, from the above survey it is clear that the EEA EFTA states are obliged to take over most relevant EU legislation in the area of free movement of workers, their employment and conditions of work. There are no substantial exceptions that would exempt them from some of fundamental EU rules.

Nevertheless, any conclusions on the equivalence of EU and EEA rules would be premature unless we deal with the question whether the interpretation of EU

34 Directive 2005/36/EC of the European Parliament and of the Council of 7 September 2005 on the recognition of professional qualifications, OJ L 255, 30.9.2005, p. 22, including its amendments.

35 Commission Decision 2007/172/EC of 19 March 2007 setting up the group of coordinators for the recognition of professional qualifications, OJ L 79, 20.3.2007, p. 38.

36 Council Directive 77/249/EEC of 22 March 1977 to facilitate the effective exercise by lawyers of freedom to provide services, OJ No L 78, 26.3.1977, p. 17; Directive 98/5/EC of the European Parliament and of the Council of 16 February 1998 to facilitate practice of the profession of lawyer on a permanent basis in a Member State other than that in which the qualification was obtained, OJ L 77, 14.3.1998, p. 36, and their amendments specified in the Annex

37 Commission Recommendation 89/601/EEC of 8 November 1989 concerning the training of health personnel in the matter of cancer, OJ No L 346, 27.11.1989, p. 1.

38 F.e. Council Directive 89/391/EEC of 12 June 1989 on the introduction of measures to encourage improvements in the safety and health of workers at work, OJ No L 183, 29.6.1989, p. 1 .

39 Council Directive 79/7/EEC of 19 December 1978 on the progressive implementation of the principle of equal treatment for men and women in matters of social security, OJ No L 6, 10.1.1979, p. 24; Directive 2006/54/EC of the European Parliament and of the Council of 5 July 2006 on the implementation of the principle of equal opportunities and equal treatment of men and women in matters of employment and occupation (recast), OJ L 204, 26.7.2006, p. 23.

40 F.e. Council Directive 98/59/EC of 20 July 1998 on the approximation of the laws of the Member States relating to collective redundancies, OJ L 225, 12.8.1998, p. 16; Directive 2008/94/EC of the European Parliament and of the Council of 22 October 2008 on the protection of employees in the event of the insolvency of their employer (Codified version), OJ L 283, 28.10.2008, p. 36-42.

$283,28.10 .2008$, p. 36). Council Directive 91/533/EEC of 14 October 1991 on an employer's obligation to inform employees of the conditions applicable to the contract or employment relationship, OJ No L 288, 18.10.1991, p. 32. Directive 96/71/EC of the European Parliament and of the Council of 16 December 1996 concerning the posting of workers in the framework of the provision of services, OJ L 18, 21.1.1997, p. 1. 
and EEA rules is the same and whether identical exemptions from the free movement rules are available.

\section{Notes on structural sources of heterogeneity between EU and EEA law}

Except a direct disapplication of EEA law equalling to an open breach of EEA law, there are several other risks complicating a full application of relevant EU law. These concern primarily:

- the interpretation of EU law-origin rules vis-à-vis their interpretation by the CJEU

- the procedures for transposition of EU law and, especially, the use of safeguard measures. ment?

4.1. Variability in the interpretation of mirror provisions under EEA Agree-

\subsubsection{Judicial apprehension of mirror provisions}

The EU law principles for interpretation of mirror provisions in external agreements were articulated by the CJEU in Polydor case ${ }^{41}$ where the CJEU formulated a context-related interpretation. ${ }^{42}$ Consequently, that similarity of terms in EU external agreements and EU law does not automatically mean that the CJEU interpretation of the relevant EU law would apply to the interpretation of the contested provision of the agreement. ${ }^{43}$ Much will depend on the aim and context of the provision of the agreement compared to the objectives and context of the EU law. ${ }^{44}$

In relation to the EEA Agreement it could be recalled that in its negative Opinion $1 / 91^{45}$ on its first draft the CJEU refused the competence of the proposed EEA Court as it would intrude in its exclusive powers under EU law, especially its task to preserve autonomy of Community legal order. ${ }^{46}$ The CJEU pointed out to differences between objectives and context of both integration projects. ${ }^{47}$ Based on this the interpretation of mirror provisions were also scru-

41 270/80 Polydor; ECLI:EU:C:1982:43.

42 Comp. Thym, Daniel, Zoetewej-Turhan, Margarite (eds). Rights of Third-country Nationals under EU Association Agreements. Leiden/Boston: Brill/Nijhoff, 2015, p. 205.

43 Comp. point 15 of Polydor decision.

44 See C-312/91 Metalsa, ECLI:EU:C:1993:279, point 11; commentary at f.e. Thym, Daniel, Zoetewej-Turhan, Margarite (eds). Rights of Third-country Nationals under EU Association Agreements. p. 106.

45 Opinion 1/91 on the EEA Agreement, ECLI:EU:C:1991:490. For a detailed commentary see f.e. Brandtner, B.: The 'Drama' of the EEA Comments on Opinions 1/91 and 1/92, 3 EJIL (1992) 300-328.

46 See Opinion 1/91, point 35.

47 Comp. especially points $15-17$. 
tinised. ${ }^{48}$ Consequently, difference of both integration projects could also justify diverging interpretation of individual provisions of both treaties (and corresponding acts).

\subsubsection{EEA Agreement rules}

The EEA agreement tried to avoid differences in the enlarged internal market. The aim of homogeneity in all EEA states could be reached only with respect to CJEU case law, which is crucial for shaping the regulation of the internal market. Thus, the EEA Agreement set up exact rules on the interpretation of mirror provisions and established a duel effect of the CJEU case law depending a certain decision delivered. Under art. 6 of the EAA Agreement:

- the interpretative judgments of the CJEU delivered prior to the date of signature $^{49}$ of the EEA Agreement are binding. This means that substantively the same provisions of the EEA agreement and EU law should be interpreted in the same way. In this regard it is important to recall that the aim to create internal market was announced by the White Paper issued in 1985 with the prospect to reach the aim in the year 1992. The establishment of the internal market was strongly supported by the CJEU; consequently, most of the principle-setting case law was adopted untill the beginning of the 90's; still, some of the key cases such as Bos$m a n^{50}$ were adopted after this date;

- interpretative judgments of the CJEU delivered after the date of signature of the EEA are not explicitly covered in art. 6. The "impact" of CJEU case law is regulated in Agreement establishing EEA Surveillance Authority and EFTA Court. ${ }^{51}$ According to its art. 3, para 2, in the interpretation of identical provisions of the EU law and EEA Agreement, a due account should be paid to the principles laid down by the relevant rulings. ${ }^{52}$

In order to avoid legal inconsistencies after 1992 the EEA Agreement created mechanisms how to deal with differences in the interpretation of the CJEU and EFTA Court. The homogeneity of interpretation is protected especially through procedures set up in art. 105-107 EEA Agreement. The aim is to secure as uniform interpretation as possible. ${ }^{53}$ In this process an important role is played by the EEA Joint Committee that keeps a constant review of the CJEU and EFTA case law. A dispute on the interpretation of identical EU and EEA Agreement

48 Comp. points 42 .

49 The EEA Agreement was signed on 2 May 1992.

50 C-415/93 Bosman, ECLI:EU:C:1995:463.

51 This agreement was adopted by EFTA states in order to implement obligations set up in EEA Agreement.

52 See art. 3, para 2 of Agreement between the EFTA States on the Establishment of a Surveillance Authority and a Court of Justice, OJ L 344, 31.1.1994, p. 3.

53 Comp. Art. 105. para 1. 
provisions may be referred to the Joint Committee also by contracting parties (comp. art 111 EEA Agreement). If the problem is not settled by the Joint Committee, it may be referred to the CJEU to give a ruling on that issue or finally may lead to the adoption of unilateral action by a Member State (especially safeguard measures under art. 112 EEA Agreement).

Evidently, the procedures for taking over EU law are constructed so that there would be a high consistency between interpretation of EU and EEA law. Complexity of these provisions show that it was a crucial issue for the contracting parties. This reflects the aim of really a free movement of workers with absence of any restrictions except those presumed in the EU law and EEA Agreement. Any unilateral solution is a last resort choice, though it is not fully excluded. It does not seem that this could be an accessible way to efficiently and, above all, systematically disregard selected rules on the free movement of workers by an EEA EFTA Member State.

\subsection{Disruptions of homogeneity of EEA rules: some remarks}

Except the preceding discussion on the interpretation of mirror provision there are actually other means how to contest EU law rules or disregard them by EEA EFTA states. This may concern especially:

- the process of their implementation on the EEA level

- the use of exceptions presumed in art. 28 EEA Agreement and

- the use of safeguard measures.

\subsubsection{Implementation of EU law under EEA Agreement}

The first danger to the requirement of homogeneity of free movement rules is based on the fact that the EU internal market law including the free movement of goods does not become automatically part of EEA Agreement. Thus, the art. 7 of the EEA Agreement empowers the EEA Joint Committee to decide on insertion of EU legislation in the relevant annex of the EEA Agreement. ${ }^{54}$ The art. 102 para 1 of the EEA Agreement seems to be quite strict and does not give a choice whether to implement the concerned act or not. The implementation is done by each Member State (f.e. through adoption of legislation by national parliament). Still, under art. 103 the binding effect of EEA Joint Committee decision may be subject to the fulfilment of national constitutional requirements in a Member State. If these constitutional requirements are not overcome, this may lead to provisional suspension of the contested act and further procedures for solving the problem are initiated. ${ }^{55}$ We assume that potentially this may be a way for a Member State to obstruct the insertion of unwanted rules in its legal order.

54 For detailed procedures for implementation of EEA relevant acts see: http://www.efta.int/ eea/eea-institutions/eea-decision-making.

55 See in that regard art. 103 para 2 in connection with 102, paras 5 and 6. 


\subsubsection{Use of exceptions and safeguard measures}

The use of exceptions referred to in art. 28 of EEA Agreement is a possibility presumed by the agreement and can be used by Member States if (mostly case-law-based) conditions are fulfilled. In principle these conditions mirror EU law provisions and can be used in similar situations as by EU Member States. Previous considerations on the interpretation of mirror provisions are applicable also in this context. Nevertheless, as far as we know their use has not been much discussed even though they might be of interest to EEA EFTA states.

Last but not least, it has been suggested that the UK as a signatory of EEA Agreement could systematically and even permanently have recourse to the safeguard measures presumed in art. 112 and 113 of the EEA Agreement. ${ }^{56}$ We assume that these considerations would go against objectives of the EEA Agreement. The use of safeguard measures refer to crisis-like situations, should be exceptional and not planned in advance. Even though this might be "a last resort" legally presumed possibility, we suppose that the UK should frankly say what are its intentions in the area of free movement of persons whether or to what extent it is going to preserve it. The consensus on this issue should be embodied in the exit agreement.

\section{Conclusions and final considerations}

First of all, the EEA law is not straightforwardly EU law and in EEA Agreement there are structural sources of possible divergence in regulation. We assume that the aim of homogeneity does not mean that the provisions must be totally the same in every detail. The overall aim should be the functionality of the internal market including the EEA EFTA states; the general functionality should enable to reflect well justified local differences.

We think that joining the EEA Agreement would be mutually advantageous solution for both the EU and the UK, as it would secure close bonds between the EU and the UK. Still, the characteristics of EEA integration should play a central role in the process of decision whether to accede the EEA Agreement or not. It cannot be well expected that the EEA principles and objectives would substantially change according to UK's desires. Particularly, any advance plans not to rely on the principles of the Agreement, including the free movement of workers, and more on the exceptions must be refused. The same is true in relation to any practice in that regard after its potential accession to the EEA Agreement. The

56 See f.e. Yarrow, George. Brexit and the Single Market. Essays in Regulation. p. 17-19, available at: http://www.rpieurope.org/Publications/Yarrow_Brexit_and_the_single_market. pdf. The recourse to safeguard measures is reflected also in other papers, though it is not expected on a daily basis, see f.e. North, Richard, Oulds, Robert. Market Solution: Flexcit: Flexible Exit and Continuous Development: The Definite EU Exit Plan for Britain. Epsom: Bretwalda Books, 2016, p. 17, available at: http://www.eureferendum.com/themarketsolution.pdf. 
UK should clearly say what are its priorities in individual areas, including the free movement of workers, and negotiate about them. This does not exclude that there may be a divergent interpretation of $\mathrm{EU}$ origin rules based on common agreement of all EEA partners including the UK or the UK will have recourse to envisaged restrictions of the free movement of workers including safeguard measures. However, these must be read rather strictly, as they go against the objectives of the EEA integration.

Finally, we might return to the question in the tile of this article, namely, whether the EEA Agreement is flexible or, better said, whether it is sufficiently flexible for the UK to fulfil its priorities of the movement of workers. The answer is that it has some flexibility potential but mostly for exceptional situations and not for regular use. Thus, much will depend on the vision of the UK in the area of migration. If requirement for full or dominant control wins, the EEA Agreement solution is not acceptable. If it would be sufficient for the UK to keep powers to solve more or less exceptional situations, then, the EEA solution could be well satisfactory. The decision is now on the UK to formulate its vision. 